\title{
Effect of face width of spur gear on bending stress using AGMA and ANSYS
}

\author{
Hardial Singh ${ }^{*}$ and Deepak Kumar \\ Department of Mechanical Engg.,Amity University, Haryana, India
}

Received: 1 May 2020 / Accepted: 4 October 2020

\begin{abstract}
In the present analysis, the effect of face width on the bending strength of spur gear has been studied. For this purpose face width of spur gear has been varied from $20 \mathrm{~mm}$ to $30 \mathrm{~mm}$ with a scale of $2 \mathrm{~mm}$. Geometry of spur gear has been drawn using AutoCAD and the gear model has been simulated for bending stress using analysis software (ANSYS).Analytical equations (AGMA bending equations) have been used to find out analytical solution. Bending stress has been calculated at the gear tooth for different values of load. The simulation results have been compared with analytical solutions obtained using AGMA equations. It has been found from the results that increase in face width of spur gear results in decrease in bending stress and hence increase in bending strength.
\end{abstract}

Keywords: Spur Gear / Auto CAD / ANSYS / Face Width / AGMA / Von-Mises Stress

\section{Introduction}

Machines produce work by transmitting power from one component to another. Gear drive is the most efficient drive to transmit the power. Gears can be classified based on the type of load and direction of transmitting torque. Spur gear is the most widely used gear due to its simplicity in manufacturing. Spur gears are subjected to bending and contact stresses. The bending stress is given by Lewis and AGMA equations. The assumptions while using these equations are as follows.

- Effect of radial component which produces compressive stress is neglected.

- Tangential component is uniformly distributed over the face width of gear.

- Stress concentration effect is negligible.

- At any time only one pair of gear is in contact and carries total load.

AGMA bending stress equation is given as: - Bending stress $\sigma=\frac{F_{t} \times P_{d} \times K_{s} \times K_{m} \times K_{a}}{b \times Y_{j} \times K_{v}}$ where

$\mathrm{F}_{\mathrm{t}}$ - Tangential load

b - Face width

$\mathrm{Y}_{\mathrm{j}}$ - Spur gear geometry factor

$\mathrm{K}_{\mathrm{v}}$ - Velocity factor or dynamic factor

$\mathrm{K}_{\mathrm{m}}-$ Load distribution factor

\footnotetext{
* e-mail: hardialsingh3@gmail.com
}

In the above equation all the factors have constant values except $F_{t}$ and $b . Y_{j}$ is calculated with calculation of Lewis form factor ' $\mathrm{Y}$ ' and stress concentration factor based on a fillet radius of tooth of $0.35 / \mathrm{P}$. It also depends on the number of teeth in the mating gear. This is the only factor which depends on the geometry and changes as the number of teeth changes. All other factors do not have much dependency on the geometry of the spur gear. $\mathrm{K}_{\mathrm{v}}$ indicates the severity of impact when the pairs of teeth engage. $\mathrm{K}_{\mathrm{v}}$ depends on pitch line velocity and manufacturing accuracy both. It is calculated by inverse of Barth's equation. $\mathrm{K}_{\mathrm{m}}$ accounts for non-uniform spread of the load across the face width. It depends on the accuracy of mounting, bearings, shaft deflection and accuracy of gears. This factor depends upon the face width but keep constant for face width $1 \mathrm{~mm}$ to $50 \mathrm{~mm}$. From AGMA bending stress equation it can be concluded that the stress is inversely proportional to the face width.

\section{Literature survey}

In recent years spur gear drag the focus of manufacturers and researchers on itself. Due to the growing industries competent environment there is a need to enhance the strength of machine components. Being the most important part of a machinery in industries, the improvement in the strength of spur gears has become the primary task for researchers. patil [1] has studied the effect of increasing face width of the spur gear on the bending stress and compared the results for two different numbers of teeth using Lewis 
Table 1. Design parameter and the calculation.

\begin{tabular}{lllll}
\hline S.No & Design parameter & Symbol & Description of calculative equation & Value \\
\hline $\mathbf{1 .}$ & Number of teeth & $\mathrm{Z}$ & - & 20 \\
$\mathbf{2 .}$ & Module & $\mathrm{m}$ & - & 3 \\
$\mathbf{3 .}$ & Pressure angle & $\Phi$ & Required value & $20^{0}$ \\
$\mathbf{4 .}$ & Pitch circle diameter & $\mathrm{d}$ & $\mathrm{m} \times \mathrm{Z}$ & $60 \mathrm{~mm}$ \\
$\mathbf{5 .}$ & Circular pitch & $\mathrm{C} . \mathrm{P}$ & $\Pi \times \mathrm{m}$ & $9.4248 \mathrm{~mm}$ \\
$\mathbf{6 .}$ & Addendum factor & $\mathrm{h}_{\mathrm{a}}$ & $1 \times \mathrm{m}$ & $3 \mathrm{~mm}$ \\
$\mathbf{7 .}$ & Addendum circle diameter & $\mathrm{d}_{\mathrm{a}}$ & $\mathrm{d}+\left(2 \times \mathrm{h}_{\mathrm{a}}\right)$ & $66 \mathrm{~mm}$ \\
$\mathbf{8 .}$ & Dedendum factor & $\mathrm{h}_{\mathrm{f}}$ & $1.25 \times \mathrm{m}$ & $3.75 \mathrm{~mm}$ \\
$\mathbf{9 .}$ & Dedendum circle diameter & $\mathrm{d}_{\mathrm{f}}$ & $\mathrm{d}-\left(2 \times \mathrm{h}_{\mathrm{f}}\right)$ & $52.5 \mathrm{~mm}$ \\
$\mathbf{1 0 .}$ & Base circle diameter & $\mathrm{d}_{\mathrm{b}}$ & $\mathrm{d} \times \mathrm{Cos} \Phi$ & $56.38 \mathrm{~mm}$ \\
$\mathbf{1 1 .}$ & Tooth thickness & $\mathrm{t}$ & $1.6 \times \mathrm{m}$ & $4.8 \mathrm{~mm}$ \\
$\mathbf{1 2 .}$ & Face width $($ in $\mathrm{mm})$ & $\mathrm{w}$ & - & $20,22,24,26,28,30$ \\
\hline
\end{tabular}

bending stress equation, MATLAB and finite element analysis (Ansys). Sharma et al. [2] worked on aluminium silicon carbide metal matrix composite as the material for spur gear and analyzed the effect of increasing fillet radius of teeth of spur gear on the stress, strain and total deformation using Ansys. Reduction of stress indicated the increase in bending strength of gear. Quadri et al. [3] varied number of module of spur gear and find out the value of contact stresses in FEA model and compared it with the analytical results of Hertzian equation. Rao et al. [4] worked on the strength of the spur gear and variation of contact stresses of mating gear teeth on the basis of material properties. Subbarao et al. [5] carried out computational analysis of the contact stresses in involutes spur gear using Ansys work bench. Patel and Murthy [6] comparatively analyzed bending stress for different number of teeth on the spur gear using MATLAB, AGMA equation and Ansys work bench. Tiwari and Joshi [7] compared the results of stress analysis of spur gear under Lewis equation, Hertzian equation and AGMA equations. Ambade et al. [8] examined the involutes spur gear for both contact stresses and bending stresses using finite element analysis. Joshi and Karma [9] worked on fillet radius for the spur gear with different number of teeth (say 14 and 30) and found reduction in total deformation and stresses value. Hohn et al. [10] worked on fillet radius ranging from $0.3 \mathrm{~mm}$ to $1 \mathrm{~mm}$. It has been found from the results that the load capacity related to torque increased up to 1.5 times for small sized gear. Costopoulos and Spitas [11] studied the effect of fillet radius on stress of one-side involute asymmetric teeth for special cases but in day to day working rotation in both the directions is required. In this model the reduction in stress up to $28 \%$ was measured. $\mathrm{Li}$ [12] worked on the effect of addendum on the contact strength, banding strength and the basic performance parameter. Kumar et al. [13] carried out work on the optimization of spur gear design by changing tooth profile parameters of asymmetric spur gear drive to improve the bending strength of gear. Wang [14] optimized the tooth profile based on identified gear dynamic model. He suggested a method to determine the dynamic model of a practical spur gear system. Spitas et al. [15] analyzed the spur gear for bending stress by replacing trochoidal fillet with the circular fillet teeth using FEA. Woods et al. [16] studied the effect of fillet radius of the teeth on the bending strength. It estimated an increase in the load carrying capacity by $43 \%$ as well as reduction in bending stress. Aravind et al. [18] found the stress analysis of the gear using finite element analysis and improve the load-carrying capacity by replacing the gear material. Yilmaz et al. [19] obtained the root stress and tooth deflection of biomaterial gear using finite element analysis. The results shows that bimetallic gear reduce the weight in power transmission system without effect of stress distribution. Jabbour et al. [20] calculated the distribution of the stress at the tooth root and bending stress is maximum on each line of a pair helical gear. $\mathrm{Yu}$ et al. [21] studied the influence of the addendum modification on spur gear back-side mesh stiffness and dynamics. Asymmetric mesh stiffness model was built along with time variation. This model was employed to two typical dynamic gear model to simulate the effect of modified addendum on the gear dynamics. Sánchez et al. [22] calculated the critical load conditions for bending and pitting of the internal gear using meshing stiffness at any point of contact.

This paper dear with a parametric study is conducted by varying the face width to study their effect on the bending stress of spur gear using ANSYS for modelling and stress analysis respectively.

\section{Methodology}

\subsection{Modelling of spur gear}

Here six numbers of spur gears have been modelled using AutoCAD-2017. All the design parameters have been kept same for the gears except the face width. Face width has been changed from $20 \mathrm{~mm}$ to $30 \mathrm{~mm}$ with an interval of $2 \mathrm{~mm}$ each time. The design parameters and relations are given in the Table 1 below.

Using the above design parameters 2D drawing has been created with the help of AutoCADand then converted 
into a 3D model. After modelling it was exported or saves in IGES file format for further analysis.

\subsection{Agma bending stress calculations [17]}

$$
\text { Bending stress } \sigma=\frac{F_{t} \times P_{d} \times K_{s} \times K_{m} \times K_{a}}{b \times Y_{j} \times K_{v}}
$$

where

$$
\begin{gathered}
P_{d}=\text { Diametral pitch }=\frac{Z}{D}=0.333 \\
K_{s}=\text { Size factor }=1 \\
K_{m}=\text { Load distribution factor }=1.2 \\
K_{a}=\text { Application factor }=1.2 \\
Y_{j}=\text { Geometry factor }=0.4 \\
K_{v}=\text { Dynamic factor or velocity factor }=0.8 \\
F_{t}=\text { Normal tangential load }
\end{gathered}
$$

For $F_{t}$ :

Power $(P)=5 \mathrm{~kW}=5000 \mathrm{~W}$ Speed $(\mathrm{N})=1500 \mathrm{rpm}$

$$
\begin{gathered}
\text { Torque }(\mathrm{T})=\frac{60 \times 10^{6} \times P}{2 \pi n} \\
T=\frac{60 \times 10^{6} \times 5}{2 \times \pi \times 1500}=31830.98 \mathrm{~N} . \mathrm{mm} \\
F_{t}=\frac{2 \times T}{m \times z}=\frac{2 \times 31830.98}{3 \times 20}=1061.03 \mathrm{~N}
\end{gathered}
$$

Table 2. Properties of material (structural steel).

\begin{tabular}{ll}
\hline Density & $7850 \mathrm{kgm}^{-3}$ \\
\hline Young's modulus & $2 \mathrm{E}+08 \mathrm{~Pa}$ \\
Poisson's ratio & 0.3 \\
Tensile yield strength & $2.5 \mathrm{E}+08 \mathrm{~Pa}$ \\
Tensile ultimate strength & $4.6 \mathrm{E}+08 \mathrm{~Pa}$ \\
\hline
\end{tabular}

From (ii), (iii), (iv), (v), (vi), (vii) and (ix) the equation (i) becomes:

$$
\begin{aligned}
\sigma_{A G M A} & =\frac{1061.03 \times 0.333 \times 1 \times 1.2 \times 1.2}{20 \times 0.4 \times 0.8} \\
& =79.49 \mathrm{~N} / \mathrm{mm}^{2}
\end{aligned}
$$

Bending stress for other gears has been computed using AGMA bending stress equation with the variation in face width $(22,24,26,28$ and $30 \mathrm{~mm})$. Also to study the effect on the material of spur gear the bending stress was calculated for different loads i.e. 2000, 2500 and $3000 \mathrm{~N}$.

\section{Material property}

Structural steel has been chosen as the spur gear material. The various mechanical properties of the material are given in the Table 2.

\subsection{Static structural analysis}

Static structure analysis of the spur gear modelled in AutoCAD carried out using the Finite element analysis in ANSYS 14.5 work bench. Spur gear model was imported in Ansys and material properties were assigned. In the present study the material used is structural steel which is the most suitable material for the spur gear due to its strength. The whole gear has been divided into small elements to analyse the bending stress in each element for more accurate value of stress at critical section. In this model very fine quality triangular mesh has been generated as shown in Table 3. Relevance is set to 10 and to refine the model mesh further the refinement has been applied up to a factor of 3 .

Boundary condition has been applied at the centre of the spur gear where the shaft is attached to the gear. That centre kept fixed shown in the Figure 1a with blue colour. The load applied on the face of the tooth tangentially shown in the red colour of the Figure 1b, the arrow shows the direction of force.

In the present study Von-mises stress has been computed using ANSYS for different face width to analyse the effect of the face width on bending stress at spur gear tooth. Figures 2-4 show the result obtained in the Ansys software. Due to the loading and boundary condition the spur gear tooth acts as the cantilever. The bending effect of load has been observed at the root fillet of the tooth of the spur gear. This region is the critical region for the tooth during meshing with the other gear.

Above figure shows the variation of bending stress with different face width. Due to the load the tooth bend and the maximum stress is generated at the critical region.

Table 3. Number of nodes and elements in ANSYS during meshing for various face width of spur gear.

\begin{tabular}{lllllll}
\hline Face width & $20 \mathrm{~mm}$ & $22 \mathrm{~mm}$ & $24 \mathrm{~mm}$ & $26 \mathrm{~mm}$ & $28 \mathrm{~mm}$ & $30 \mathrm{~mm}$ \\
\hline No. of nodes & 551502 & 579489 & 598303 & 648129 & 665657 & 688185 \\
No. of elements & 273982 & 287690 & 296841 & 321752 & 330291 & 341215 \\
\hline
\end{tabular}




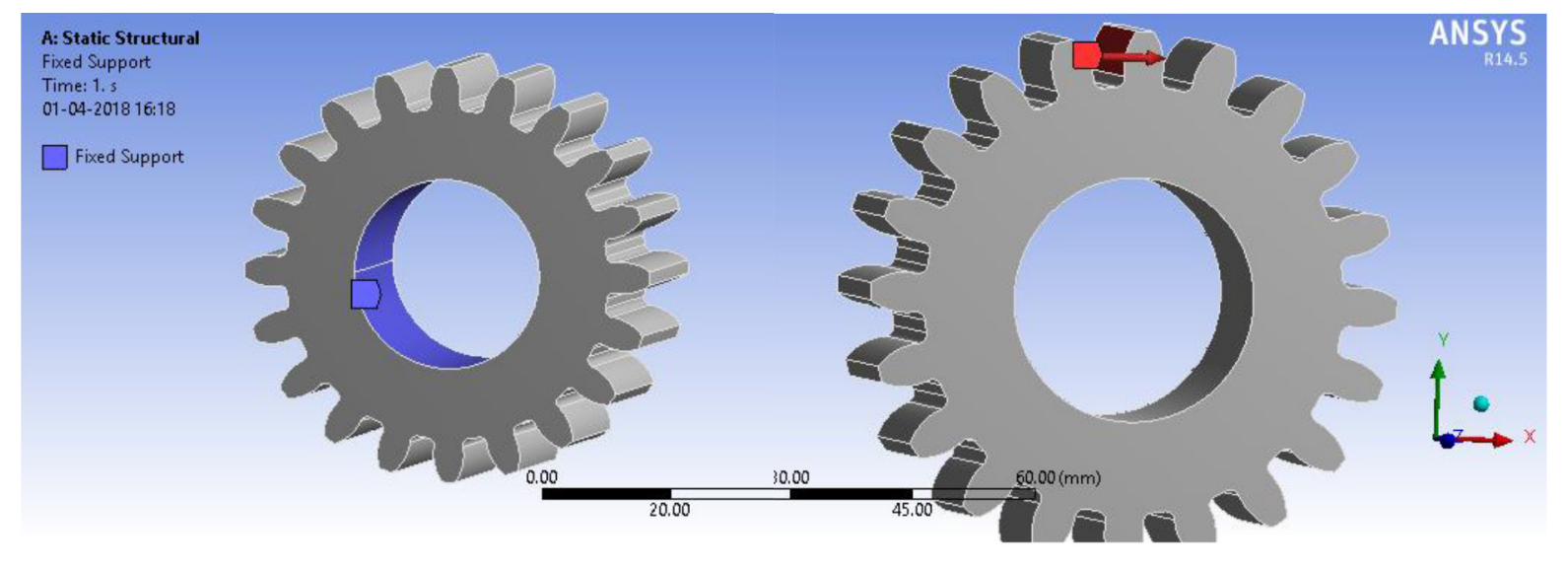

(a)

(b)

Fig. 1. (a) Fixed support at spur gear (face width $20 \mathrm{~mm}$ ); (b) loading condition and direction at $20 \mathrm{~mm}$ face width.

The maximum value of the stress is shown with the red colour at the root fillet of the tooth.

The results shown in the Figure $2 \mathrm{a}-\mathrm{f}$ has been against a load of $1061.03 \mathrm{~N}$. To optimize the design and to know whether the effect of face width on the bending stress of the spur gear teeth are true at higher loading condition, the applied load was incccresed.

\section{Results analysis}

Bending stress is calculated for different face width at $1061.03 \mathrm{~N}$ load using AGMA equations. It is found from the results that there is a reduction in the bending stress with the increase in the face width of the spur gear. The same has been shown in Table 4. Also the bending stress is computed using ANSYS software under static structure analysis. The results obtained using Ansys are shown in Table 4. The analytical and computational results are compared and it has been found that error is within the limits. Also it is found that Increasing face width will increase the stress distribution area due to which the overall effect of load decreases at the root of mating tooth. These results signifies enhancement in tooth bending strength.

Also the Bending stress of teeth of spur gear has been determined with higher loading conditions using AGMA equation and ANSYS. The value of load increased up to the tensile yield strength of the material of spur gear (structural steel). Same trend is observed for the higher loading conditions. Table 4 and Table 5 shows the effect of increasing face width on value of bending stresses at 2, 2.5 and $3 \mathrm{kN}$. The error between the AGMA and ANSYS results are similar for all loads indicating the effect of face width on bending stress is significant and independent of loading condition.

The maximum error observed between the computational results and the AGMA results is 4\%.Graphs have been plotted against these data given in the Table 4 and Table 5. Different graph have been plotted for different loading conditions, showing the variation of the bending stress at tooth of spur gear with respect to the increasing face width of the spur gear.
Figure 3 shows the variation of bending stress against face width at $1061.0329 \mathrm{~N}$ load. The range of face width is taken as 20-30 mm. In this graph there are two lines which show results on the basis of AGMA equation and ANSYS. The bending stress is observed to be $82.81 \mathrm{Mpa}$ for face width $20 \mathrm{~mm}$ and load $1061.03 \mathrm{~N}$. It has been observed from the results there is $34 \%$ reduction in bending stress when the value of face width varied from $20 \mathrm{~mm}$ to $30 \mathrm{~mm}$ and the corresponding reduced value of bending stress is 54.58 Mpa.

Figure 4 showing the variation of bending stress on spur gear tooth with respect to spur gear face width at a load of $2000 \mathrm{~N}$, with the comparison of AGMA and ANSYS bending stress results. At $2000 \mathrm{~N}$ load the ANSYS bending stress at root of the tooth of spur gear for $20 \mathrm{~mm}$ face width was found to be $156.09 \mathrm{Mpa}$, and reduced to $102.89 \mathrm{Mpa}$ for $30 \mathrm{~mm}$ face width which is $34 \%$ reduction in bending stress. AGMA bending stress at face width $20 \mathrm{~mm}$ was $149.85 \mathrm{Mpa}$ which was reduced for the face width $30 \mathrm{~mm}$ up to 99.9 Mpa, a 33.33\% reduction in stress. Comparing AGMA and ANSYS results the ANSYS shows the better reduction in results.

Figures 5 and 6 shows the decreasing slope as face width increases. The maximum stress is found to be 195.12 Mpa using Ansys at a load of $2500 \mathrm{~N}$ and face width of $20 \mathrm{~mm}$. The bending stress decreases when face width is increased to $30 \mathrm{~mm}$ stress and reaches to $128.61 \mathrm{Mpa}$. As shown in graph-4 the maximum stress was observed to be $234.14 \mathrm{Mpa}$ when the face width was $20 \mathrm{~mm}$ while it reduced to $154.33 \mathrm{Mpa}$ when the face width was increased to $30 \mathrm{~mm}$ at a load of 3000 N. For both the loading conditions the percentage reduction remains $34 \%$ when analysing in ANSYS and $33.33 \%$ when analysing in AGMA. The same slope and identical line in each plot describe the linear relation of the effect of increasing face width on the bending stress irrespective of the load.

Figure 7 shows the comparison of different loads lines if only AGMA calculated bending stress plotted against the varying face width of spur gear tooth. Whereas in graph-6 effect of increases face width on bending stress of spur gear tooth is shown with the value of stresses solved under ANSYS. 


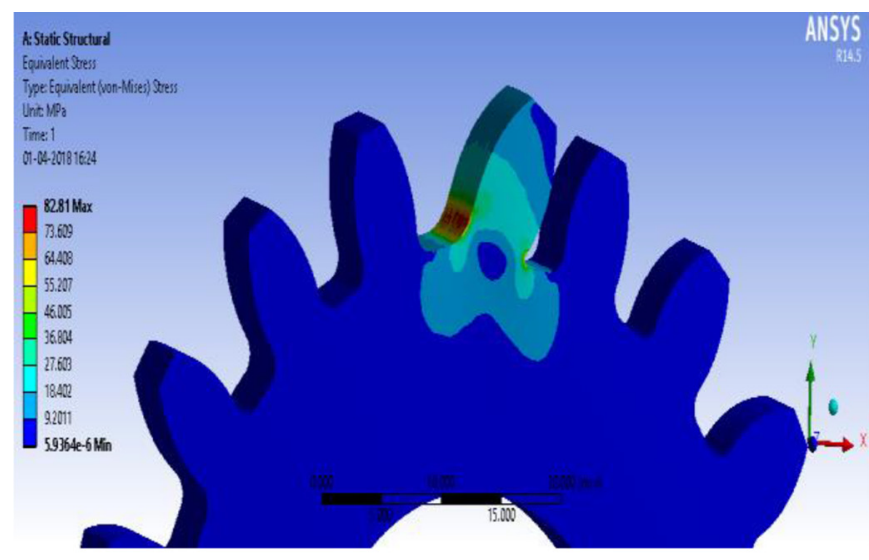

(a)

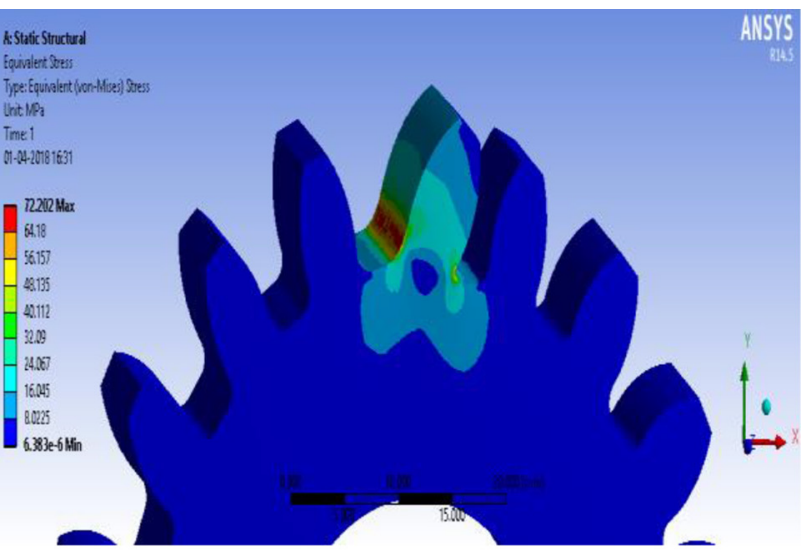

(b)

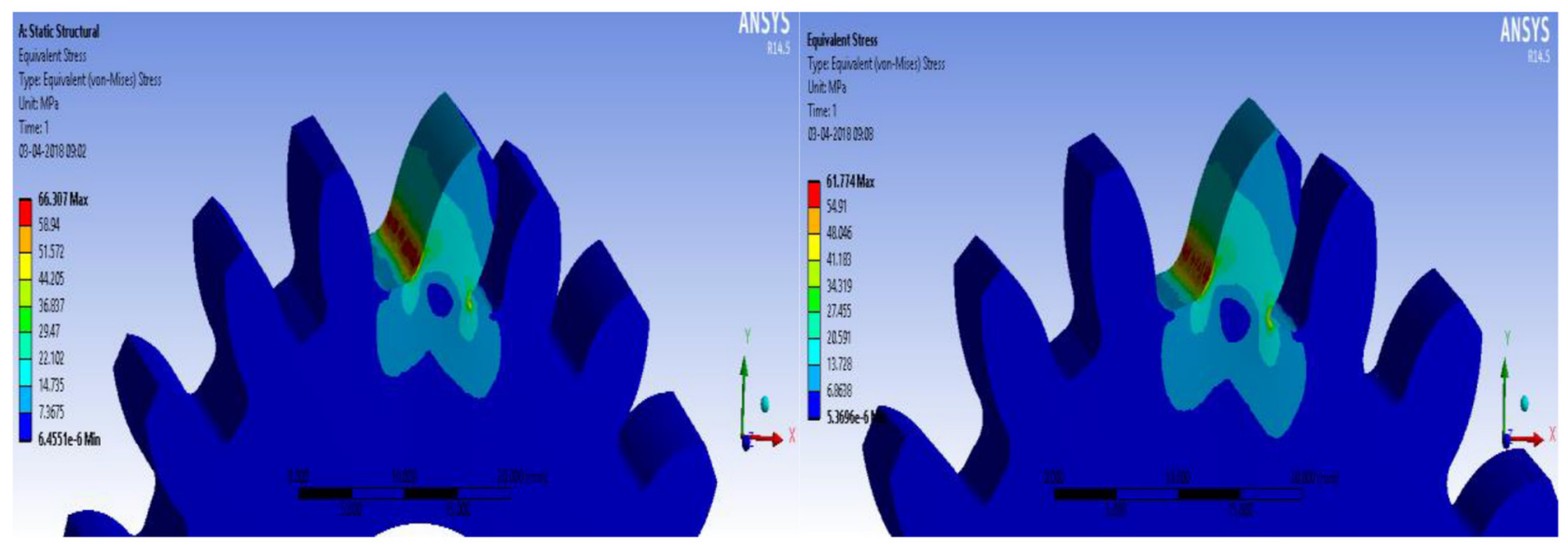

(c)

(d)

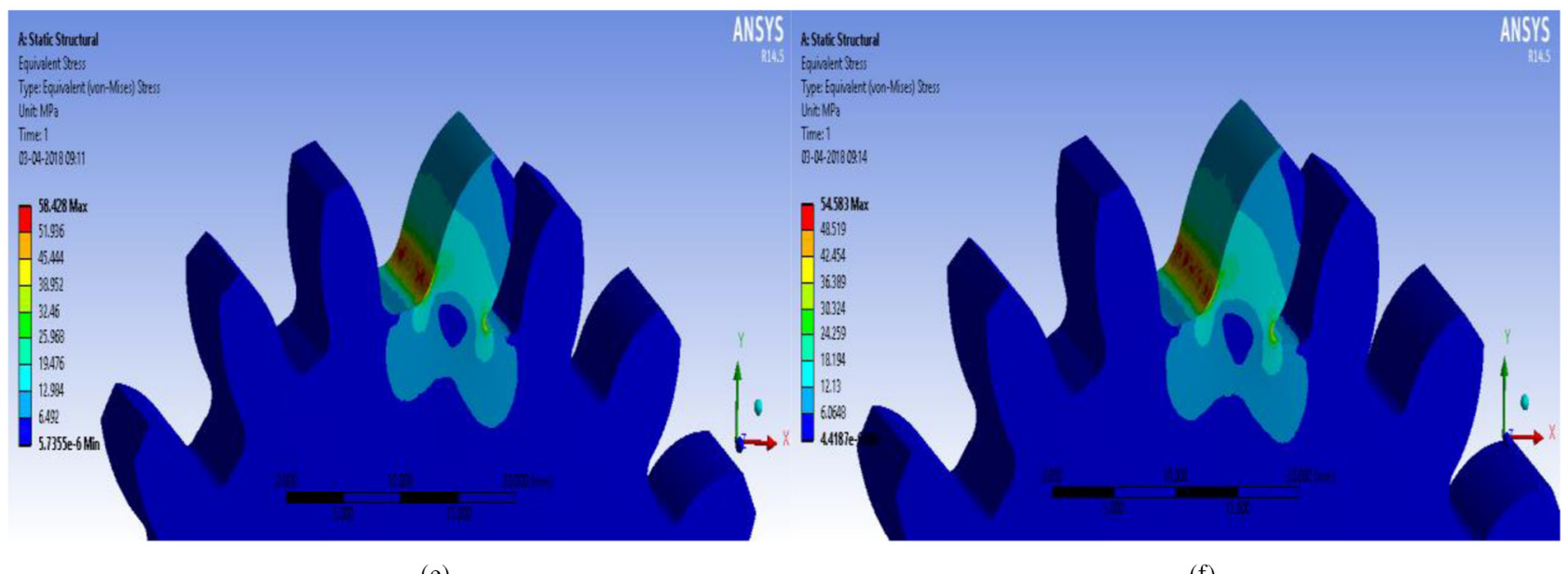

(e)

(f)

Fig. 2. (a) Von-mises stress at gear with face width $20 \mathrm{~mm}$; (b) Von-mises stress at gear with face width $22 \mathrm{~mm}$; (c) Von-mises stress at gear with face width $24 \mathrm{~mm}$; (d) Von-mises stress at gear with face width $26 \mathrm{~mm}$; (e) Von-mises stress at gear with face width $28 \mathrm{~mm}$; (f) Von-mises stress at gear with face width $30 \mathrm{~mm}$.

Analysis of bending stress has been done with changing face width and varying load Using AGMA equations. Variation of the lines (different colour for different load) or the slope of each line is somewhat same, except some negligible differences. Results show that if the load is increased beyond $3000 \mathrm{~N}$ the material of spur gear will fail resulting in the failure of gear in the drive, because it reaches its yielding stress value. This could be resolved by 


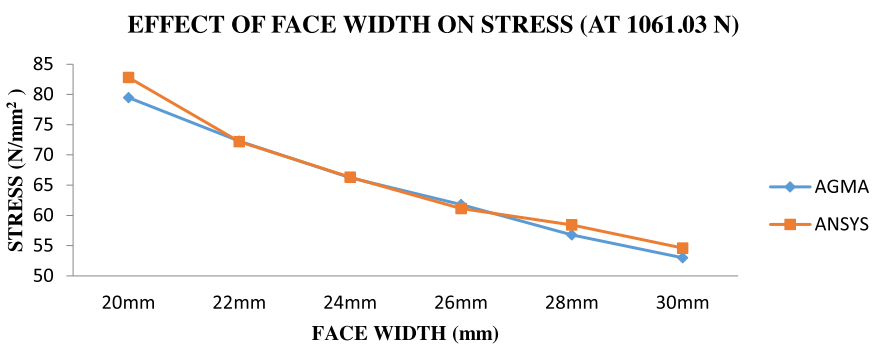

Fig. 3. Comparison of the effect of increases in face width on bending stress with AGMA and ANSYS at $1061.03 \mathrm{~N}$ of load.

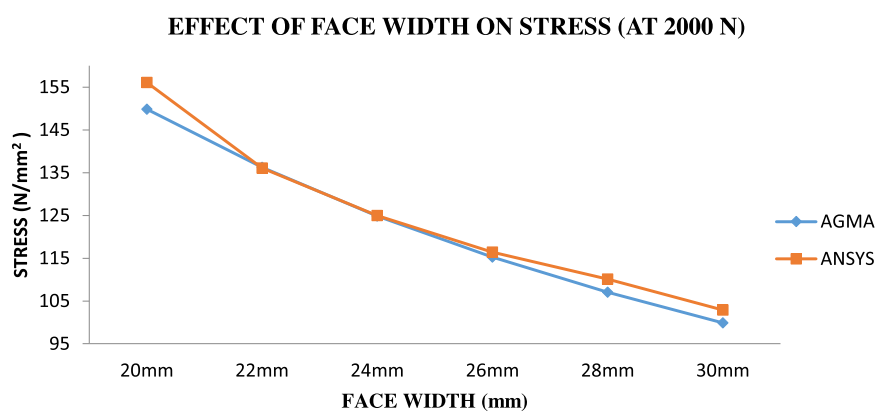

Fig. 4. Comparison of the effect of increases in face width on bending stress with AGMA and ANSYS at $2000 \mathrm{~N}$ load.

Table 4. Value of bending stresses on the teeth of spur gear using AGMA equation and ANSYS software applied load of $1061.03 \mathrm{~N}$ and $2000 \mathrm{~N}$ with varying face width.

\begin{tabular}{|c|c|c|c|c|c|c|}
\hline \multirow{2}{*}{$\begin{array}{l}\text { FACE WIDTH } \\
\text { b (in mm) }\end{array}$} & \multicolumn{2}{|c|}{ AT $1061.0329 \mathrm{~N}$} & \multirow{2}{*}{$\begin{array}{l}\text { ERROR } \\
\%\end{array}$} & \multicolumn{2}{|c|}{ AT $2000 \mathrm{~N}$} & \multirow{2}{*}{$\begin{array}{l}\text { ERROR } \\
\%\end{array}$} \\
\hline & AGMA & ANSYS & & AGMA & ANSYS & \\
\hline $20 \mathrm{~mm}$ & $79.49 \mathrm{mpa}$ & $82.81 \mathrm{mpa}$ & $4.10 \%$ & $149.85 \mathrm{mpa}$ & $156.09 \mathrm{mpa}$ & $4.20 \%$ \\
\hline $22 \mathrm{~mm}$ & $72.27 \mathrm{mpa}$ & $72.20 \mathrm{mpa}$ & $0 \%$ (aprox) & $136.23 \mathrm{mpa}$ & $136.10 \mathrm{mpa}$ & $0 \%$ (aprox) \\
\hline $24 \mathrm{~mm}$ & $66.25 \mathrm{mpa}$ & $66.31 \mathrm{mpa}$ & $0 \%$ (aprox) & $124.88 \mathrm{mpa}$ & $124.99 \mathrm{mpa}$ & $0 \%$ (aprox) \\
\hline $26 \mathrm{~mm}$ & $61.77 \mathrm{mpa}$ & $61.15 \mathrm{mpa}$ & $1 \%$ & $115.27 \mathrm{mpa}$ & $116.44 \mathrm{mpa}$ & $1 \%$ \\
\hline $28 \mathrm{~mm}$ & $56.78 \mathrm{mpa}$ & $58.43 \mathrm{mpa}$ & $3 \%$ & $107.04 \mathrm{mpa}$ & $110.13 \mathrm{mpa}$ & $3 \%$ \\
\hline $30 \mathrm{~mm}$ & $52.99 \mathrm{mpa}$ & $54.58 \mathrm{mpa}$ & $3 \%$ & $99.90 \mathrm{mpa}$ & $102.89 \mathrm{mpa}$ & $3 \%$ \\
\hline
\end{tabular}

Table 5. Value of bending stresses on the teeth of spur gear using AGMA equation and ANSYS software applied load of $2500 \mathrm{~N}$ and $3000 \mathrm{~N}$ with varying face width.

\begin{tabular}{|c|c|c|c|c|c|c|}
\hline \multirow{2}{*}{$\begin{array}{l}\text { FACE WIDTH } \\
\text { b (in mm) }\end{array}$} & \multicolumn{2}{|c|}{ AT $2500 \mathrm{~N}$} & \multirow{2}{*}{$\begin{array}{l}\text { ERROR } \\
\%\end{array}$} & \multicolumn{2}{|c|}{ AT $3000 \mathrm{~N}$} & \multirow{2}{*}{$\begin{array}{l}\text { ERROR } \\
\%\end{array}$} \\
\hline & AGMA & ANSYS & & AGMA & ANSYS & \\
\hline $20 \mathrm{~mm}$ & $187.31 \mathrm{mpa}$ & $195.12 \mathrm{mpa}$ & $4.20 \%$ & $224.78 \mathrm{mpa}$ & $234.14 \mathrm{mpa}$ & $4.20 \%$ \\
\hline $22 \mathrm{~mm}$ & $170.28 \mathrm{mpa}$ & $170.12 \mathrm{mpa}$ & $0 \%$ (aprox) & $204.34 \mathrm{mpa}$ & $204.15 \mathrm{mpa}$ & $0 \%$ (aprox) \\
\hline $24 \mathrm{~mm}$ & $156.09 \mathrm{mpa}$ & $156.23 \mathrm{mpa}$ & $0 \%$ (aprox) & $187.31 \mathrm{mpa}$ & $187.48 \mathrm{mpa}$ & $0 \%$ (aprox) \\
\hline $26 \mathrm{~mm}$ & $144.09 \mathrm{mpa}$ & $145.55 \mathrm{mpa}$ & $1 \%$ & $172.90 \mathrm{mpa}$ & $174.66 \mathrm{mpa}$ & $1 \%$ \\
\hline $28 \mathrm{~mm}$ & $133.79 \mathrm{mpa}$ & $137.67 \mathrm{mpa}$ & $3 \%$ & $160.55 \mathrm{mpa}$ & $165.20 \mathrm{mpa}$ & $3 \%$ \\
\hline $30 \mathrm{~mm}$ & $124.88 \mathrm{mpa}$ & $128.61 \mathrm{mpa}$ & $3 \%$ & $149.85 \mathrm{mpa}$ & $154.33 \mathrm{mpa}$ & $3 \%$ \\
\hline
\end{tabular}

increasing the face width of spur gear beyond $20 \mathrm{~mm}$. Spur gear with increased face width is safe because at the increased value of face width, the bending stress will not exceed its yielding stress value.

Figures 7 and 8 shows the comparison of bending stress at different loads which helps in estimating the variation of the stress at different face width and loads. Here in Figure 7, the AGMA stresses variation for different loads are similar. It does not change considerably and has a similar decreasing curve for every load. Whereas Figure 8 shows that the slope of the stress line curve is sharper for $3000 \mathrm{~N}$ load, as compared to the other loads. The overall reduction for all loads are same but the reduction when face width reduced from $20 \mathrm{~mm}$ to $24 \mathrm{~mm}$ is more for higher loads than in the lower loads as observed in the Figure 8.
In ANSYS software finite numbers of very small elements were analysed due to which it shows the maximum value of stress that could develop in spur gear material. Due to this the ANSY results are greater than that of AGMA results but with a very small error value.

\section{Conclusion}

The Results showed reduction in bending stress with an increase in the face with negligible error. Bending stress values obtained using both the methods do not exceed the yield stress and hence safe and within the acceptance imit. The analysis showed that the gear will not fail if face width is more than $20 \mathrm{~mm}$, as the bending stress at greater face 
EFFECT OF FACE WIDTH ON STRESS (AT 2500 N)

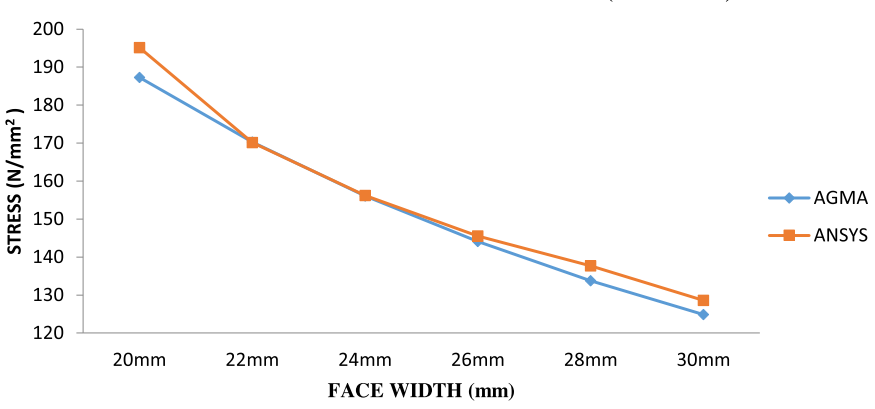

Fig. 5. Comparison of the effect of increases face width on bending stress with AGMA and ANSYS at $2500 \mathrm{~N}$ of load.

\section{EFFECT OF FACE WIDTH ON STRESS (AT 3000 N)}

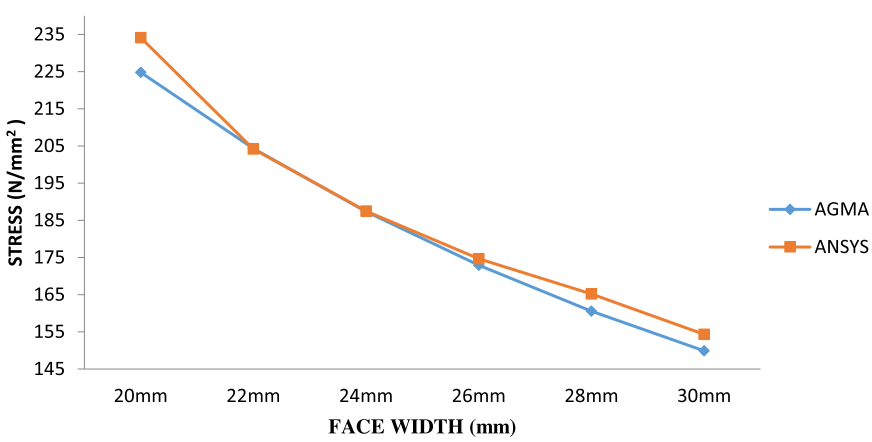

Fig. 6. Comparison of the effect of increases face width on bending stress with AGMA and ANSYS at $3000 \mathrm{~N}$ of load.

\section{EFFECT OF FACE WIDTH ON STRESS (AGMA)}

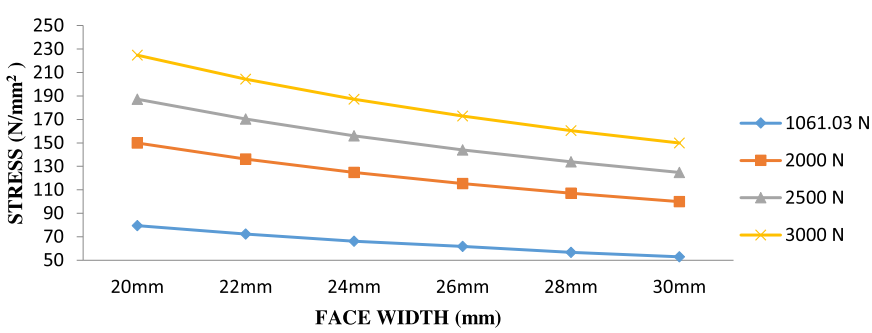

Fig. 7. Comparison of the effect of increases face width on bending stress with analytical value (AGMA) at varying loads.

\section{EFFECT OF FACE WIDTH ON STRESS (ANSYS)}

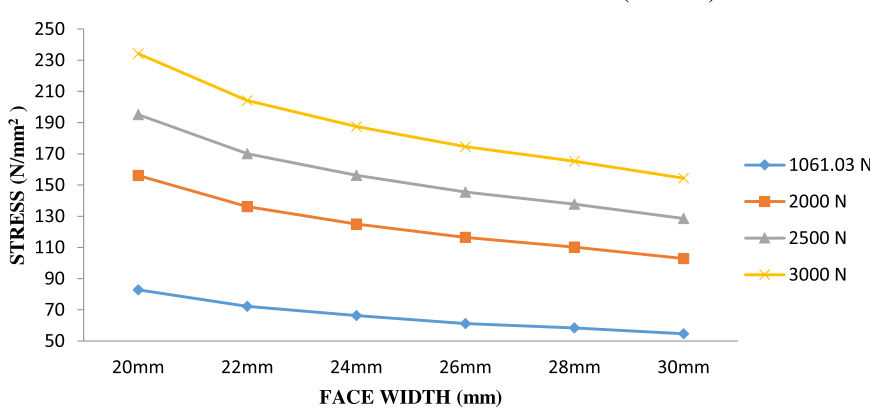

Fig. 8. Comparison of the effect of increases face width on the Von-mises stress with software values (ANSYS) at varying load. width will not cross the yield stress value of the material. An increase in the face width of the spur gear evidently increases the load carrying capacity of gear. Increase in bending strength has been achieved with increase in face width of spur gear. The value of load does not affect the variation of bending stress with respect to face width. This implies that the reduction in bending stress at the tooth of the spur gear is same at any value of load. Increasing load beyond $3000 \mathrm{~N}$ will fail the spur gear having face width $20 \mathrm{~mm}$, as it crosses the yielding limit of the material of gear.

\section{References}

1. A. Patil, Bending stress analysis of spur gear, Int. J. Appl. Sci. 5, 422-426 (2017)

2. A. Sharma, M. L. Aggarwal, L. Singh, Effect of fillet radius on aluminium silicon carbide metal matrix composite spur gear, International Journal of Recent Advances in Mechanical Engineering (IJMECH) 4, 137-148 (2015)

3. S.A.N. Quadri, D.R. Dolas, Contact Stress Analysis of Involute Spur gear under Static loading, Int. J. Sci. 4, 593-596 (2015)

4. P.S. Rao, N. Sriraj, M. Farookh, Contact Stress Analysis of Spur Gear for Different Materials using ANSYS and Hertz Equation, Int. J. Modern Studies in Mechanical Engineering. 1, 45-52 (2015)

5. D.V. Subbarao, Y. Dilip Kumar, T. Tirupati, Computational analysis of contact stresses in involute spur gears using ANSYS, Int. J. Sci. Res. 2, 2049-2454 (2014)

6. I. Patel, M.S. Murthy, Comparison of bending stresses for different number of teeth of spur gear obtained using MTLAB Simulink with AGMA and ANSYS, IJETT, 4, 3141-3144 (2013)

7. S.K. Tiwari, U.K. Joshi, Stress analysis of mating involute spur gear teeth, International Journal of Engineering Research \& Technology. 1, 1-12 (2013)

8. V.V. Ambade, A.V. Vanalkar, P.R. Gajbhiye, Involute gear tooth contact and bending stress analysis, International Journal of Computational Engineering Research. 3, 30-36 (2013)

9. A. Joshi, V.K. Karma, Effect on strength of involute spur gear by changing the fillet radius using FEA, Int. J. Eng. Res. 2, 1-5 (2011)

10. B.R. Hohn, P. Oster, C. Brayoff, Size and material influence on the tooth root, pitting, scuffing and wear load carrying capacity of fine module gears, Gear Technology, 34-40 (2011)

11. T. Costopoulos, V. Spitas, Reduction of gear fillet stresses by using one-sided involute asymmetric teeth, Int Mechanism and Machine Theory 44, 1524-1534 (2009)

12. S. Li, Effect of addendum on contact strength, bending strength and basic performance parameters of a pair of spur gears, Mechanism and Machine Theory 43, 1557-1584 (2008)

13. S. Kumar, D.V. Muni, G. Muthuveerappan, Profile modification, a design approach for increasing the tooth strength in spur gear, Mechanism and Machine Theory 43, 829-858 (2008)

14. Y. Wang, Optimized tooth profile based on identified gear dynamic model, Mechanism and Machine Theory 42, 1058-1068 (2007) 
15. C.A. Spitas, V.A. Spitas, Generating interchangeable $20^{\circ}$ spur gear sets with circular fillets to increase load carrying capacity, Gear Technology, 28-34 (2006)

16. J.L. Woods, S.R. Daniewicz, R. Nellums, Increasing the bending fatigue strength of carburized spur gear teeth by presetting, International Journal of Fatigue. 21, 549-556 (1999)

17. Dudley's, "Gear hand book" 2nd ed, pp. 6.15-6.22

18. V. Aravind, S. Adharsh, D. Prakash, K. Babu, Stress analysis on functionally graded spur gear. in: K. Vijay Sekar, M. Gupta, A. Arockiarajan (Eds), Advances in Manufacturing Processes. Lecture Notes in Mechanical Engineering. Springer, Singapore, 2019
19. T.G. Y1lmaz, O. Dogan, F. Karpat, A comparative numerical study of forged bi-metal gears: Bending strength and dynamic response. Mechanism and Machine Theory, 141, 117-135 (2019)

20. Jabbour, Toni, G. Asmar, Tooth stress calculation of metal spur and helical gears. Mechanism and Machine Theory 92, 375-390 (2015)

21. W. Yu, C.K. Mechefske, M. Timusk, Influence of the addendum modification on Spur Gear Back-side Mesh Stiffness and Dynamics, Journal of Sound and Vibration, 1-19 (2016)

22. M.B. Sánchez, M. Pleguezuelos, J.I. Pedrero, Strength model for bending and pitting calculations of internal spur gears. Mechanism and Machine Theory 133, 691-705 (2019)

Cite this article as: Hardial Singh, Deepak Kumar, Effect of face width of spur gear on bending stress using AGMA and ANSYS, Int. J. Simul. Multidisci. Des. Optim. 11, 23 (2020) 